\title{
ファインバブルの計測法
}

\author{
島 岡 治 夫 ${ }^{\mathrm{a}}$ \\ a (株)島津製作所 分析計測事業部 ( ⿳ 604-8511 京都府京都市中京区西ノ京桑原町 1)
}

\section{Measurement Technologies for Fine Bubbles}

\section{Haruo SHIMAOKA ${ }^{\text {a }}$}

${ }^{a}$ Analytical \& Measuring Instruments Division, Shimadzu Corporation(1, Nishinokyo Kuwabara-cho, Nakagyo-ku, Kyoto-shi, Kyoto 604-8511)

Keywords : Fine Bubble, Ultrafine Bubble, qLD

\section{1. はじめに}

ファインバブルは，文字通り「微細気泡」を意味しており， 気泡径が $1 \mu \mathrm{m}$ 未満を「ウルトラファインバブル」, 気泡径 が $1 \mu \mathrm{m}$ 以上 $100 \mu \mathrm{m}$ 未満のものを「マイクロバブル」に分 類し, 両者を合わせて「ファインバブル」と呼称することが 国際規格(ISO/TC281 Fine bubble technology)で定められてい る。ファインバブルは, 洗浄, 殺菌・滅菌から, 動植物の成 長促進, 鮮魚の品質維持, 医療・製薬, 美容・化粧品など, 1 次産業から 3 次産業に至る幅広い分野での基礎研究および 実用化を目指す応用研究が進められている。

ファインバブルを様々な産業分野に応用するためには, ファインバブルの特性を客観的かつ定量的に評価し, ファイ ンバブルそのものの特性と個々の応用分野(アプリケーショ ン)における効果の関係を明確に評価し示す必要がある。ファ インバブルの特性を評価する場合, その対象は, 気泡(気体 粒子) とそれが分散している媒体から構成される「ファイン バブル分散媒体(Fine bubble dispersion)」となる。ファイン バブル分散媒体は, その用途や目的によっては, 多様な気体
(ガス)および媒体(液体, 固体)によって構成される可能性が ある。しかし, 現時点ではほとんどの場合, 媒体としては水 が用いられるので, ここでは,「ファインバブル分散水」を 前提とした気泡径分布測定すなわち気泡のサイズと濃度 (粒 子量)の測定について紹介する。

\section{2. 気泡測定に適用できる粒子径分布の測定手法}

ファインバブルは気体粒子であり, 固体または液体粒子用 に開発され発展してきた下記のような粒子径分布測定手法を 利用することができる。

(1) レーザ回折・散乱法 ${ }^{1)}$

(2) 動的光散乱法 ${ }^{2)}$

(3) 粒子軌跡解析法 ${ }^{3)}$

(4) 共振式質量測定法 ${ }^{4)}$

(5) 電気的検知帯法 ${ }^{5)}$

(6) 動的画像解析法 ${ }^{6)}$

(7) 遮光法 ${ }^{7)}$

それぞれの粒子径分布測定手法の測定範囲を図 1 に示す。 四に示すようにカバーできる粒子径範囲は測定手法によって

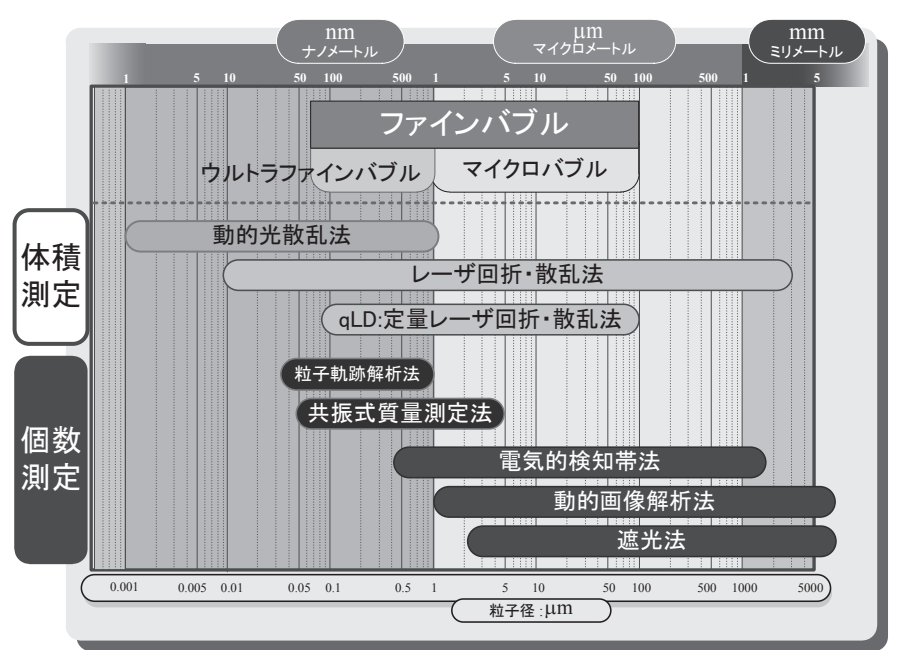

図 1 測定手法がカバーできる粒子径範囲 
異なり, $1 \mu \mathrm{m}$ 以上のマイクロバブルの測定に適したものと, $1 \mu \mathrm{m}$ 未満のウルトラファインバブルの測定に適したものが ある。また，体積基準で測定するものと個数基準で測定する ものがある。さらに, 研究室のような清浄かつ理想的な環境 下で，不純物を含まないサンプルの測定に適したものと，適 切な前処理方法を確立すれば，ファインバブルが実際に利用 される環境下での測定にも対応できるものがある。したがっ て, ファインバブルの応用分野や評価対象に応じて, 適切な 手法や装置を選択しなければならない。

図 2 には，レーザ光が照射された粒子(ファインバブル)か ら発せられる散乱光を利用して粒子径分布 (サイズと粒子量 の関係)を求める三つの手法の測定原理を示す。実際にこれ らの手法はファインバブルの測定によく使われている。これ らは散乱光を測定に用いるという点では共通しているが，測 定原理が異なり，適用できる対象 (粒子径範囲, 濃度範囲)も 異なるので混同しないように注意が必要である。

「動的光散乱法」と「粒子軌跡追跡法」は, 粒子のブラウ ン運動の速度を利用する。ブラウン運動が適用できる粒子径 範囲は, 基本的に $1 \mu \mathrm{m}$ 以下であるが, その範囲内でも, 比 較的大きな粒子はゆっくり動き，小さな粒子は速く動き回る。 この現象を粒子径の決定に利用する。

「動的光散乱法」では，ブラウン運動の速度を散乱光の時 間的変化すなわち「ゆらぎ」として検出するが,「粒子軌跡 解析法」では, 粒子の運動をビデオ画像として記録し, それ ぞれの粒子 (光点)の軌跡を解析して粒子径を決定している。 また，「粒子軌跡解析法」では，気泡のサイズと同時に，光 点の数をカウントすることによって, 個数濃度 $($ 個 $/ \mathrm{mL})$ を評 価することができるが，個数濃度が 10 億個 $/ \mathrm{mL}$ を超えると 希釈が必要になる場合がある。「動的光散乱法」では, 通常, 粒子量の合計を $100 \%$ とする相対粒子量を求めることになり, いまのところ体積濃度や個数濃度に関する情報は得られない。

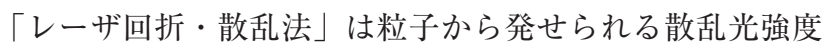
の角度 (散乱角) 依存性を利用する。大きな粒子から発せられ る散乱光は前方 (レーザの照射側とは反対方向)に集中し，小 さな粒子から発せられる散乱光は前方だけでなく側方や後方 にも広がる。この散乱光強度の散乱角度に依存したパターン から粒子径を求めることができる。
図 3 には実際の装置で使用される「レーザ回折・散乱法」 のシステム構成を示す。ファインバブル発生システムで発生 された「ファインバブル分散水」は, フローセルを通過して 排出される。フローセルを通過している多数のファインバブ ル(気体粒子)にレーザを照射し，そこから発せられる散乱光 を前方散乱光センサ, 側方散乱光センサおよび後方散乱光セ ンサで検出して, その光強度分布パターンからファインバブ ルの粒子径分布を算出する。

従来の「レーザ回折・散乱法」では, 合計が $100 \%$ となる 相対粒子量しか求められなかったが，それを拡張した「定量 レーザ回折・散乱法(Quantitative laser diffraction method)」 ${ }^{8)}$ を用いると体積濃度 (単位 : $\mu \mathrm{L} / \mathrm{mL}$ ) や個数濃度(単位：個 / $\mathrm{mL}$ ) としての粒子径分布 (サイズと濃度の関係)を求めること ができる。このために, 個数濃度が既知な PSL (ポリスチレ ンラテックス)標準粒子を用いてキャリブレーション(校正) を行う。さらに，ファインバブル(空気)と PSL 粒子の屈折 率の差異を, Mie 散乱理論 ${ }^{1)}$ を用いて理論的に補正すること によって体積濃度や個数濃度が算出できる。

図 4 には,「定量レーザ回折・散乱法」を用いたウルトラファ インバブル (気泡径が $1 \mu \mathrm{m}$ 未満)の測定結果を示す。ここで は濃度の異なる 3 種類のサンプルを測定し, その結果を表と グラフで示している。グラフの横軸は気泡径(単位 $: \mathrm{nm}$, 対 数スケール), 縦軸は個数濃度 (単位; 億個 $/ \mathrm{mL}$ ) である。

気泡径はいずれも，100 nm 前後であるが，それぞれの個

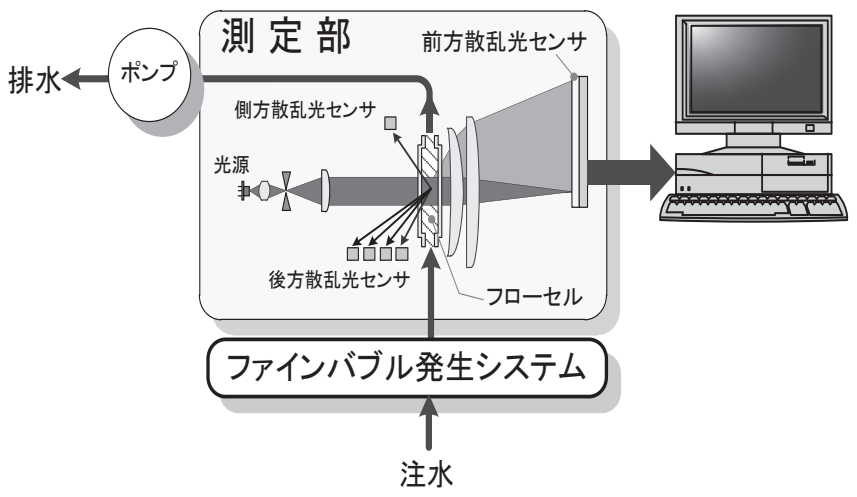

図３レーザ回折・散乱法のシステム構成

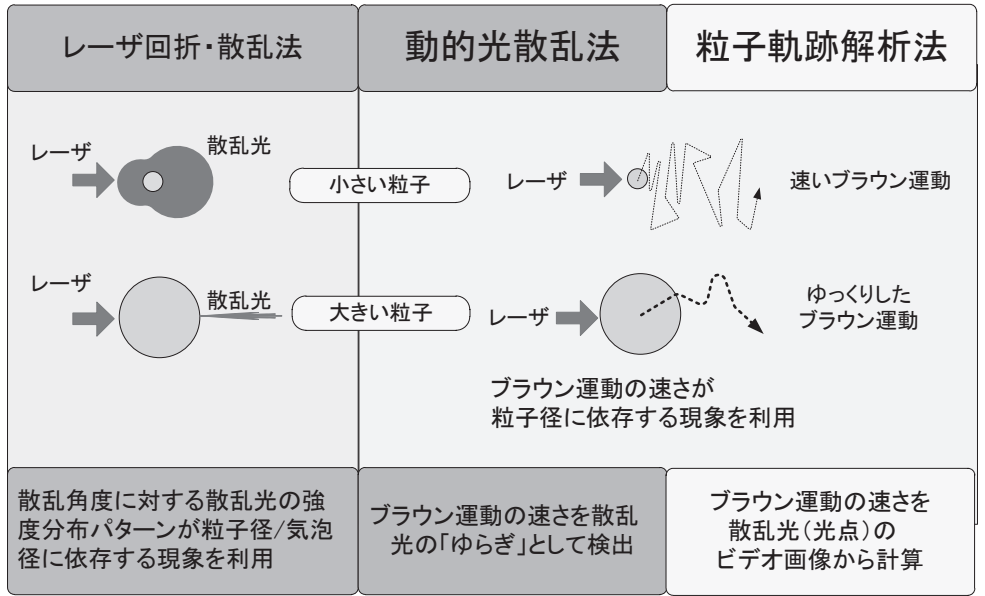

図 2 散乱光を用いる粒子径(気泡径)測定手法 
数濃度すなわち $1 \mathrm{~mL}$ 中に含まれるウルトラファインバブル の個数は, 26 億 7 千万個, 9 億 7 千万個, 5 億 5 千万個となっ ている。従来の「レーザ回折・散乱法」では, 粒子量の合計 がすべて $100 \%$ になるので，濃度の比較を行うことができな かったが，拡張された「定量レーザ回折・散乱法」では濃度 の比較ができるようになった。

ファインバブルの効果を評価するためには, 個数濃度の測 定が重要であり, 現時点では個数濃度が評価できる「定量レー ザ回折・散乱法」と「粒子軌跡解析法」が多く用いられてい る。「粒子軌跡解析法」はウルトラファインバブルにのみ適 用可能だが,「定量レーザ回折・散乱法」はウルトラファイ ンバブルとマイクロバブルの両方を評価することができる。 滅菌や美容へのファインバブルの応用においては，0.5〜 $5 \mu \mathrm{m}$ 程度の領域が効果的であるという研究結果が報告され ており, これらの用途では「定量レーザ回折・散乱法」が有 利である。

\section{3. 測定結果を正しく把握するために}

前述したように，それぞれの粒子径測定手法は，ブラウン 運動や散乱光強度の角度依存性などの固有の物理現象 - 物理 量を用いて測定をおこなっているので，粒子径や粒子量・粒 子濃度の定義そのものが異なるため，異なる手法を用いて測 定した結果は完全には一致しない。さらに, 相対粒子量では なく個数濃度が評価できる手法は限られている。

現在, ファインバブルの国際標準化の活動(ISO/TC281 Fine bubble technology)においては,「サイズ(気泡径)インデッ クス」や「個数濃度インデックス」などの表現を用いること が提案されている。すなわち, 測定值ではなくファインバブ ルの特性を評価するための「指標」という理解が望ましい。

一方，粒子径分布の粒子量・粒子濃度を表現するには，体 積基準と個数基準の 2 つの手段がある。体積基準では, どの 気泡径のファインバブルの体積が大きいかを評価し, 個数基 準では, どの気泡径の個数が多いかを評価する。簡単な計算 によって，体積基準の結果を個数基準に変換できるし，逆に 個数基準のデー夕を体積基準に変換することも可能である。

図 5 に示すように，全く同じ測定対象を同一の測定手法で

\begin{tabular}{|c|c|c|c|c|}
\hline \multicolumn{2}{|c|}{$\begin{array}{c}\text { 気泡径区間 } \\
\text { 単位 }(\mathrm{nm})\end{array}$} & \multicolumn{3}{|c|}{$\begin{array}{l}\text { 個数 (億個) } / \mathrm{mL} \\
(10 \mathrm{E} 8 \text { 個 } / \mathrm{mL})\end{array}$} \\
\hline 下限 & 上限 & サンプルA & サンプルB & サンプルC \\
\hline 268 & 302 & 0.0 & 0.0 & 0.0 \\
\hline 237 & 268 & 0.2 & 0.1 & 0.0 \\
\hline 211 & 237 & 0.3 & 0.1 & 0.0 \\
\hline 187 & 211 & 0.8 & 0.3 & 0.1 \\
\hline 166 & 187 & 1.1 & 0.4 & 0.2 \\
\hline 147 & 166 & 2.0 & 0.7 & 0.4 \\
\hline 130 & 147 & 2.6 & 0.9 & 0.5 \\
\hline 116 & 130 & 3.4 & 1.2 & 0.7 \\
\hline 103 & 116 & 3.9 & 1.4 & 0.8 \\
\hline 91 & 103 & 4.5 & 1.6 & 0.9 \\
\hline 81 & 91 & 4.3 & 1.6 & 0.9 \\
\hline 72 & 81 & 1.9 & 0.7 & 0.4 \\
\hline 64 & 72 & 1.5 & 0.5 & 0.3 \\
\hline 56 & 64 & 0.2 & 0.1 & 0.0 \\
\hline 気泡䋨 & 個数 & 26.7 & 9.7 & 5.5 \\
\hline
\end{tabular}

測定した場合であっても，体積基準と個数基準では，全く印 象の異なるグラフになる。グラフは，（a)体積基準，（b) 個数 基準のいずれの場合も, 横軸は粒子径(気泡径 単位 : $\mu \mathrm{m}$ ), 縦軸は相対粒子量 (単位：\%) となっている。なお, 個数濃度 （単位：個 $/ \mathrm{mL}$ ) は個数基準の一つであり, 体積濃度(単位： $\mu \mathrm{L} / \mathrm{mL}$ ) は体積基準の一つである。

表 1 と表 2 には，それぞれ粒子径比率 1 対 10 および 1 対

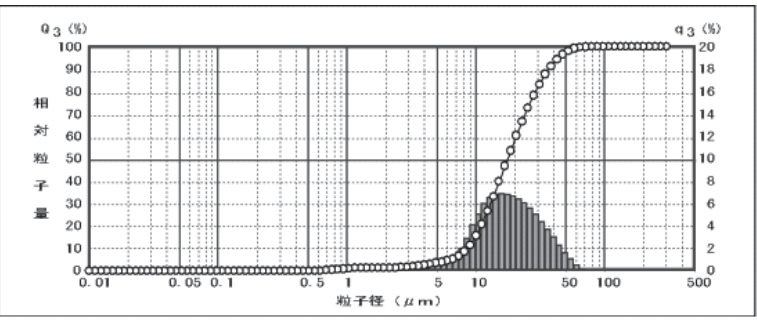

(a)体積基準

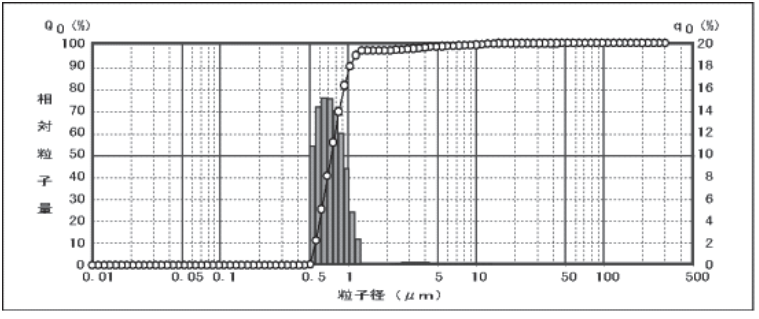

(b)個数基準

図 5 体積基準と個数基準

表 1 体積基準と個数基準の比較 (粒子径比率 : 1 対 10)

\begin{tabular}{l|c|c}
\hline 粒子径比率 & 1 & 10 \\
\hline 粒子量比率(体積基準) & 1 & 1 \\
\hline 粒子量比率(個数基準) & 1,000 & 1 \\
\hline
\end{tabular}

表 2 体積基準と個数基準の比較(粒子径比率 : 1 対 100)

\begin{tabular}{l|c|c}
\hline 粒子径比率 & 1 & 100 \\
\hline 粒子量比率(体積基準) & 1 & 1 \\
\hline 粒子量比率(個数基準) & $1,000,000$ & 1 \\
\hline
\end{tabular}

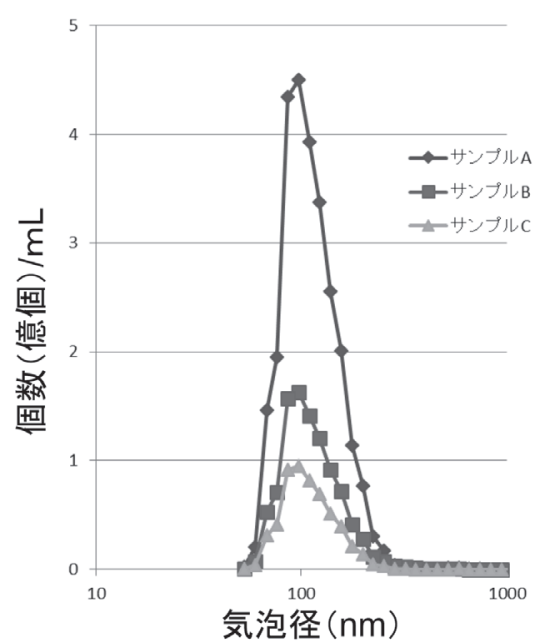

図 4 定量レーザ回折・散乱法によるウルトラファインバブルの測定結果 
100 の場合について粒子量比率の違いを記載している。表 1 のように粒子径比率が 1 対 10 の場合(例えば $100 \mathrm{~nm}$ と $1 \mu \mathrm{m}$ の場合), 体積基準では粒子量の比率が 1 対 1 でも, 個数基 準では 1000 対 1 になり, 粒子径の比率が 1 対 100 の場合(例 えば $100 \mathrm{~nm}$ と $10 \mu \mathrm{m}$ の場合), 体積基準では粒子量の比率 が 1 対 1 でも，個数基準では $1,000,000$ 対 1 になる。これは, 個数基準では小さい方の粒子量を大きく拡大して見せること になり，体積基準では小さい方の粒子量を小さく見せること になる。

ウルトラファインバブルを評価する場合, 粒子量としては 個数濃度 (単位：個 $/ \mathrm{mL}$ )を用いることが多いようだが，これ は個数基準であり, 小さい方の気泡の特性しか見ていないこ とにもなる。コンタミやマイクロバブルのように粒子径が比 較的大きな存在を確認するためには体積基準や体積濃度(単 位： $\mu \mathrm{L} / \mathrm{mL})$ として測定結果を見てみることも重要である。

\section{4.ファインバブル測定の基本的な考え方と留意点}

「ファインバブル分散水」のサンプルに含まれる粒子の一 般的な構成は，図6のようになる。サンプルには，ウルトラ ファインバブル，マイクロバブル以外にも，固体粒子や液体 粒子(エマルジョンなど)が含まれている。

一般的な粒子径分布測定においては，サンプルに含まれる すべての粒子状物質のサイズと粒子量が測定されるので, 固 体粒子や液体粒子が測定対象になる場合, ファインバブルが コンタミ成分となるが，ファインバブルの測定においては， 固体粒子や液体粒子がコンタミ成分となる。この場合, 意味 のある測定結果を得るためには，コンタミ成分の粒子量が測 定対象の粒子量に比べて，無視できる程度に少ないことが前 提となる。あるいは, 測定対象を含まない原水と測定対象を 含むサンプルの測定結果を比較して，原水にはなく，サンプ ルにのみ存在する測定対象の粒子量を評価するという考え方 もある。

ファインバブル測定の場合には, 図 7 に示すようにファイ ンバブル発生前 (原水) とファインバブル発生後のサンプルを 比較することになる。

一般的に, ウルトラファインバブルを発生する場合, マイ クロバブルも同時に発生している。ウルトラファインバブル

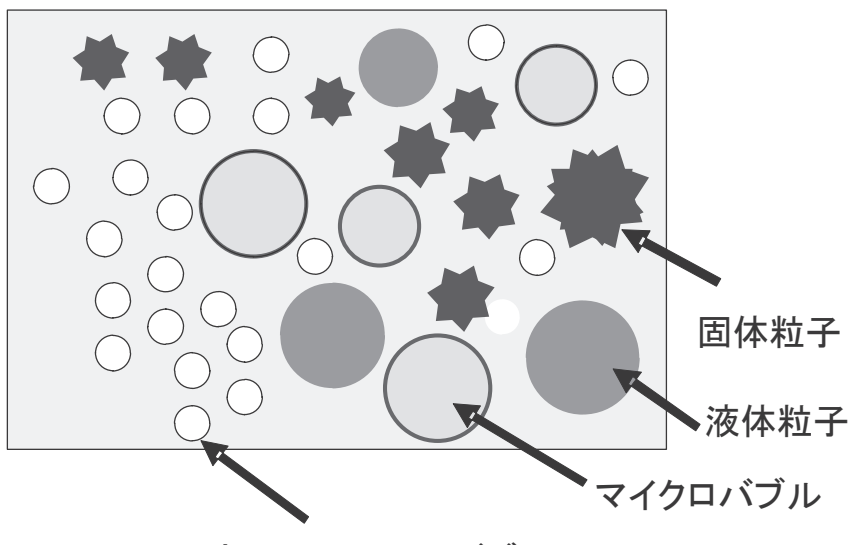

ウルトラファインバブル
を測定するためには，マイクロバブル $(1 \mu \mathrm{m}$ 以上) の存在も コンタミ成分と同様に測定における誤差要因になるので，除 去する必要がある。サンプリングの後, 一定時間放置してお けば，マイクロバブルは浮上または消失するので簡単に除去 することができる。

一方，マイクロバブルをサンプリングして測定することは 極めて困難であり, $10 \mu \mathrm{m}$ 以上のマイクロバブルを測定する 場合は, インラインの測定を検討する必要がある。少なくと も, マイクロバブルを容器に入れて送付し, 測定装置を所有 する研究機関で測定を行うことは考えられない。

「ファインバブル分散水」を使用環境によって分類すると 図 8 のようになる。サイズ (気泡径) と個数濃度が, 容易に測 定できるのは実験室環境において，コンタミ成分が無視でき るように生成された「ファインバブル分散水」に限定される。 現場環境で使用される「ファインバブル分散水」に関しては, 供給源で採取されたものは，原水に含まれるコンタミ成分の 量が比較的少ない場合には, 原水との比較によって, サイズ と個数濃度を何とか評価できる可能性はある。ところが，使 用中や使用後に採取された「ファインバブル分散水」はコン 夕ミ成分が多く含まれている可能性が高く, それを除去する ことが困難なので，ファインバブルのサイズと個数濃度の評 価は極めて困難である。

\section{5.おわりに}

ここでは，ファインバブルの特性評価のひとつであるサイ ズと濃度の評価を中心に測定手法や測定において留意すべき

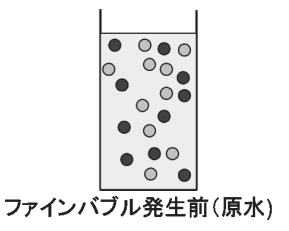

○ ファインバブル

○固体/液体粒子
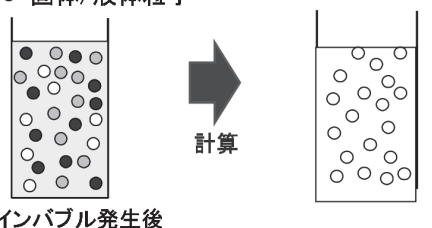

A

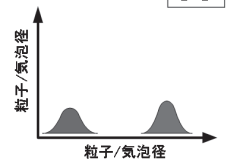

B
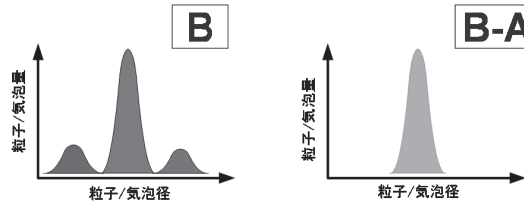

図 7 ファインバブル発生前後の比較

実験用に生成されたファインバブル水 （コンタミが無視できる。）

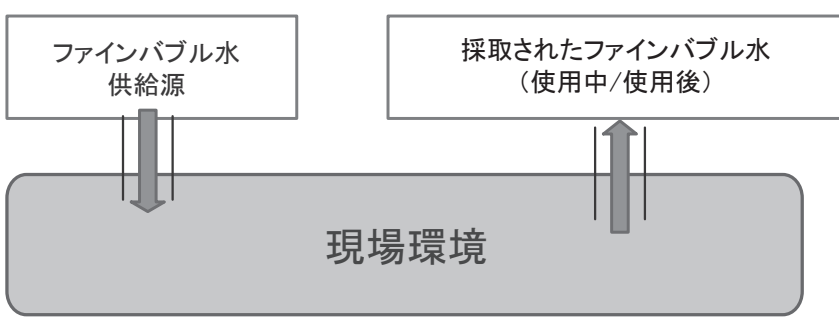

図 8 ファインバブル分散水の分類 
ポイントについて紹介した。ファインバブルの様々な分野で の応用を進めるためには，ファインバブルの特性と効果の関 係を明確にすることがきわめて重要である。このようなファ インバブルの効果を評価するためには, 洗浄, 殺菌・滅菌か ら, 動植物の成長促進, 鮮魚の品質維持, 医療・製薬, 美容· 化粧品などの応用分野において, 個別のアプリケーションご とにファインバブルの効果を評価する手法を確立し規格化を 進めていかなければならない。

ファインバブルは新しい技術であり, 基礎研究, 新産業創 出および国際標準化が同時並行的に進められている。通常は, 基礎研究の成果が蓄積され, 応用研究や産業化が進展した後 で，国際標準化が行われるので，これらを同時に進めようと しているファインバブルの事例は, かつてない挑戦というこ とになる。基礎研究の段階においても，例えば，測定前に必 要なサンプリングや前処理に関する一定の規格が整備されて いれば，世界各地の大学や研究機関において実施された実験 結果の比較が容易になり，成果を共有することによって，基 礎研究や応用研究における無駄な重複を低減し, 効率的な研
究開発が産業化のプロセスを促進することにつながる。

ファインバブルの産業化については，日本が諸外国に先ん じている部分が多く，経済的波及効果を含めて期待が高まっ てきている。その期待を裏切らないためにも, ファインバブ ルの特性評価に続いて, 様々な応用における効果の定量的な 評価についても手法の確立を行い, 国際標準化を検討してい かなければならない。

(Received March 31, 2017)

\section{文献}

1 ) 粉体工学会編; 粒子径計測技術, p.145（日刊工業新聞社, 1994).

2 ) 田中克治; 粉体技術, 7, (7), 44 (2015).

3 ) 入江文子; 粉体技術, 7, (7), 34 (2015).

4 ）池田英幸; 粉体技術, 7, (7), 38 (2015).

5 ) 粉体工学会編; 粒子径計測技術, p.199 (日刊工業新聞社, 1994).

6 ) 粉体工学会編; 粒子径計測技術, p.215 (日刊工業新聞社, 1994).

7 ) 粉体工学会編; 粒子径計測技術, p.181 (日刊工業新聞社, 1994).

8 ) 島岡治夫; 光技術コンタクト, $5 \mathbf{5},(2), 12$ (2017). 